\title{
REGULASI DAN IMPLEMENTASI PENDIDIKAN INFORMAL
}

\author{
1)Ihat Hatimah \\ ${ }^{1}$ Dosen Jurusan PLS Universitas Pendidikan Indonesia \\ Email: Ihat.hatimah@yahoo.co.id
}

\begin{abstract}
Regulation of informal education stipulated in the Law on National Education System No. 20 of 2003 Article 27, namely: 1) informal education activities carried out by the family and the environment in the form of learning activities independently, 2) Results of education referred to in subsection (1) is recognized equal to formal and informal education after students pass the exam in accordance with national standards of education, 3) provisions regarding the admission of informal education as referred to in paragraph (2) shall be regulated further by a government regulation. Implementation of informal education the most obvious is through the family, because the family is the lead agency and the first for children's development. Parents should be able to be a parent of intelligent loving that can be realized in the form of: 1) facilitating children to grow and be happy, 2) train independence, 3) instilling confidence, 4) help facilitate reading books that are useful, 5) invite children to play wholeheartedly, 6) facilitates to communicate, solve problems, make decisions, 7) invites move or move, 8) guiding when watching television.
\end{abstract}

Keywords: regulation, informal education, informal education implementation

\section{A. PENDAHULUAN}

Keluarga adalah lembaga pendidikan yang pertama dan utama bagi perkembangan anak. Keluarga memiliki fungsi merawat dan melatih anak, menjaga dan mendidik anakanak, sehingga pembinaan anak dalam keluarga merupakan refleksi dari tanggung jawab dan peran orang tua sebagai pendidik pertama dan utama. Dalam mendidik anak, hendaknya orang tua menggunakan pendekatan yang bersifat kasih sayang. Kasih sayang merupakan tindakan yang dapat menumbuhkan keindahan dan menyejukkan, sehingga dapat memunculkan keharmonisan dan kenyamanan antara orang tua dengan anakanaknya.Keluarga diharapkan mampumenciptakan suasana lingkungan yang mendukung terwujudnya tujuan pendidikan yaitu meningkatkan pengetahuan, keterampilan dan sikap mental yang diperlukan untuk mengembangkan diri sesuai potensi yang dimiliki oleh anak-anaknya.

Orang tua harus memahami kedudukan anak dalam keluarga, hal ini sesuai dengan ungkapan Amirudin (2011), yaitu:

1) Anak adalah amanah

Allah Swt. Mengamanahkan anak untuk dididik sesuai dengan nilai-nilai yang telah digariskan. Amanah adalah suatu perkara yang akan diminta pertanggungjawaban atas orang yang dipercaya memegangnya. Orang tua harus faham bahwa ketika melaksanakan amanah dalam hal mendidik anak-anak harus betul-betul sesuai aturan yang sudah digariskan, sehingga orang tua mampu mempertanggungjawabkan 
dalam melaksanakan amanah tersebut.

2) Anak adalah generasi penerus Orang tua mempunyai tanggung jawab dalam hal menyiapkan anak-anaknya sebagai generasi mendatang. Orang tua harus memberikan perhatian secara maksimal dengan kualitas yang baik dalam mendidik anak, sehingga ketika mendidik anak tidak hanya sisa waktu, tetapi mendidik anak merupakan prioritas.

3) Anak sebagai investasi akhirat Berkat didikan orang tua yang baik, diharapkan anak mampu menyelamatkan dari siksa api neraka. Hal ini sesuai dengan (H.R.Muslim), Rasulullah saw. Bersabda: "Apabila manusia mati terputus amalannya kecuali dari tiga perkara: sedekah jariah, ilmu bermanfaat, atau anak shaleh yang mendoakannya".

Menurut UUSPN NO 20 tahun 2003 pasal 13 jalur pendidikan terdiri atas pendidikan formal, nonformal dan informal yang dapat saling melengkapi dan memperkaya.

Berdasarkan rumusan tersebut di atas, menunjukkan bahwa pendidikan merupakan tanggung jawab bersama antara keluarga, masyarakat dan pemerintah. Keluarga memiliki peran penting dalam pembentukan karakter anak, diantaranya mencakup pembentukan sikap, keterampilan dasar, pendidikan agama, budi pekerti, sopan santun, estetika, kasih sayang, menanamkan kebiasaan-kebiasaan dan menanamkan norma dan nilainilai yang berlaku dalam masyarakat. Apabila kehidupan keluarga dibina dengan baik maka kehidupan masyarakat akan baik, karena keluarga merupakan unit terkecil dari masyarakat.

\section{B. KAJIAN LITERATUR}

Berdasarkan Undang-Undang RI No 20 Tahun 2003 tentang Sistem Pendidikan Nasional, pasal 3 tertuang bahwa: "Pendidikan Nasional berfungsi mengembangkan kemampuan dan membentuk watak serta peradaban bangsa yang bermartabat dalam rangka mencerdaskan kehidupan bangsa, bertujuan untuk mengembangkan potensi peserta didik agar menjadi manusia yang beriman dan bertanggung jawab kepada Tuhan Yang Maha Esa, berakhlak mulia, sehat, berilmu, cakap, kreatif, mandiri, dan menjadi warga Negara yang demokratis serta bertanggung jawab".

Tujuan pendidikan tidak akan terwujud apabila kesadaran keluarga tidak mendukung pentingnya pendidikan, sehingga untuk mencapai tujuan tersebut diperlukan berbagai upaya dan penguatan tentang pentingnya keluarga dalam membentuk manusia Indonesia yang berkualitas yang bisa dilakukan secara mandiri, dan hasilnya dapat diakui sama dengan pendidikan formal dan nonformal. Hal ini sebagaimana yang tertuang dalam UUSPN No 20 tahun 2003 pasal 27 yaitu:

1) Kegiatan pendidikan informal yang dilakukan oleh keluarga dan lingkungan berbentuk kegiatan belajar secara mandiri

2) Hasil pendidikan sebagaimana dimaksud 
pada ayat (1) diakui sama dengan pendidikan formal dan nonformal setelah peserta didik lulus ujian sesuai dengan standar nasional pendidikan

3) Ketentuan mengenai pengakuan hasil pendidikan informal sebagaimana dimaksud pada ayat (2) diatur lebih lanjut dengan peraturan pemerintah.

Menurut UUSPN NO 20 tahun 2003 pasal 13 jalur pendidikan terdiri atas pendidikan formal, nonformal dan informal yang dapat saling melengkapi dan memperkaya. Dalam penyelenggaraan pendidikan harus ada kesesuaian dan keserasian antara pendidikan yang diselenggarakan di sekolah, masyarakat dan keluarga. Menurut Sudjana (2007:47), keterkaitan antara ketiga lingkungan pendidikan tersebut harus dibina dan dikembangkan di atas prinsip konsistensi, kontinuitas dan konvergensi. Prinsip konsistensi memberi arah bahwa kegiatan pendidikan di tiga lingkungan pendidikan itu harus berjalan serasi dan saling menunjang. Prinsip kontinuitas mempunyai makna bahwa pendidikan di ketiga lingkungan pendidikan itu berhubungan erat dan berkesinambungan. Prinsip konvergensi menekankan bahwa tujuan pendidikan di ketiga lingkungan pendidikan tersebut mengarah pada pencapaian tujuan pendidikan nasional.

Peraturan Pemerintah No 17 tahun Tahun 2010 tentang Pengelolaan dan penyelenggaraan pendidikan secara eksplisit menyatakan bahwa pendidikan informal dilakukan oleh keluarga dan lingkungan yang berbentuk kegiatan belajar seacara mandiri. Pendidikan dalam keluarga dan lingkungan dimaknai sebagai pendidikan yang sumber pengetahuan dan proses pembelajarannya dari keluarga dan lingkungan.

Kecakapan hidup setiap individu menjadi dasar kokohnya bangunan keluarga dan lingkungan. Hal ini sesuai dengan pendapat Dadan dkk (2012), kecakapan hidup seseorang bersumber dari berbagai kecerdasan diantaranya:

1) Kecerdasan spiritual merupakan kecerdasan manusia untuk memahami dan melaksanakan ajaran agama

2) Kecerdasan intelektual merupakan kecerdasan manusia terutama digunakan manusia untuk berhubungan dengan mengelola alam

3) Kecerdasan emosional merupakan kecerdasan manusia terutama digunakan untuk mengelola emosi diri sendiridan hubungan dengan orang lain dan masyarakat dengan sikap empati

4) Kecerdasan sosial merupakan kecerdasan manusia terutama digunakan untuk berhubungan dan bekerja sama dengan orang lain dan masyarakat serta hubungan antar manusia 
5) Kecerdasan estetik merupakan kecerdasan manusia yang berhubungan dengan rasa keindahan, keserasian dan kehamonisan

6) Kecerdasan kinesteti merupakan kecerdasan manusia yang berhubungan denga koordinasi gerak tubuh seperti yang dilakukan penari, atlet, pertukangan.

\section{METODE PENELITIAN}

Keluarga adalah lembaga pendidikan yang utama dan pertama dalam membentuk karakter anak sebagai generasi penerus bangsa. Hal ini sesuai dengan resolusi Majelis Umum PBB (dalam Megawangi:2003) bahwa: "fungsi utama keluarga adalah sebagai wahana untuk mendidik, mengasuh, dan mensosialisasikan anak, mengembangkan kemampuan seluruh anggotanya agar dapat menjalankan fungsinya di masyarakat dengan baik, serta memberikan kepuasan dan lingkungan yang sehat guna tercapainya keluarga sejahtera".Hal ini didasarkan pada pengertian dari keluarga itu sendiri, yaitu:

1) Keluarga adalah sekumpulan orang yang hidup bersama dalam tempat tinggal bersama dan masing-masing anggota merasakan adanya pertautan batin sehingga terjadi saling memperhatikan dan saling menyerahkan diri. (Soelaeman, 1994).

2) Keluarga sebagai tempat berkumpulnya beberapa orang yang memiliki ikatan, dan biasanya sebagai ikatan turunan. Pada umumnya, orang-orang dalam keluarga tersebut disebut ayah/bapak, ibu, dan anak. Unsur ini dinamakan keluarga inti. Dalam susunan keluarga masih terdapat unsur yang lain, seperti kakek, nenek, paman, bibi serta yang lainnya. Keluarga juga dapat didefinisikan semagai umat kecil yang memiliki pimpinan dan anggota yang mempunyai tugas dan kerja serta hak dan kewajiban bagi masingmasing (Zubaidi:2011) anggotanya

3) Keluarga adalah unit satuan masyarakat yang terkecil yang sekaligus merupakan suatu kelompok kecil dalam masyarakat

4) Keluarga merupakan suatu ikatan atas dasar perkawinan antara dua orang dewasa yang berlainan jenis yang hidup bersama antara seorang laki-laki dengan perempuan yang sudah mempunyai anak atau tanpa anak baik anaknya sendiri atau adopsi dan tinggal dalam sebuah rumah tangga. (Setiawan, 2006)

5) Keluarga adalah kelompok sosial yang terdiri atas dua orang atau lebih yang mempunyai ikatan darah, perkawinan atau adopsi. Di dalamnya terdapat ayah, ibu, dan beberapa anak (keluarga inti) serta kakeknenek, paman, bibi, cucu, ipar, keponakan, mertua, ipar, misan, dan anggota lainnya yang sering dikatakan dengan kerabat (keluarga besar). (Vembrianto, 1993:33)

Dalam keluarga terjadi proses pendidikan, sebab dalam keluarga 
terjadi proses usaha orang tua untuk mendidik/membimbing anakanaknya menjadi anak yang berguna, baik untuk kepentingan dirinya, keluarganya, lingkungannya maupun negaranya.

Peran orang tua memberikan pendidikan pada anak-anaknya tidak bersifat terbatas, baik dilihat dari waktu maupun materinya. Pendidikan keluarga tidak hanya bertujuan agar anak dapat berbicara, menyanyi, memasak atau kepentingan dirinya sendiri, tetapi orang tua senantiasa memberikan berbagai informasi/keterampilan terhadap anak-anaknya yang ada kaitannya dengan kehidupan sosial.

Sifat-sifat yang dimiliki oleh lembaga pendidikan keluarga adalah: 1) lembaga pendidikan tertua, 2) lembaga pendidikan informal, 3) lembaga pendidikan pertama dan utama, 4) bersifat kodrati.

$$
\text { Keluarga }
$$

merupakan

pendidikan tertua di dunia, sesuai dengankeberadaan manusia, sejak turunnya Nabi Adam as.dan istrinya Siti Hawa, benih-benih keluarga mulai ada. Melalui keluarga terjadi pewarisan berbagai hal bagi perkembangan anak-anaknya. Sampai saat sekarang keluarga masih diperlukan keberadaannya untuk turut serta berperan secara aktif dalam berbagai bidang kehidupan, sebab melalui keluarga anak ditempa kepribadiannya untuk mengisi dan berperan dalam kehidupan bermasyarakat yang lebih luas.

Sebagai lembaga pendidikan informal, pendidikan dalam keluarga tidak diprogram secara baku, sehingga tidak memiliki kekakuan dalam hal struktur materi, waktu penyelenggaraan, metode yang digunakan serta evaluasi hasil belajar.

Keluarga sebagai lembaga pendidikan utama dan pertama membuktikan bahwa anak pertama kali menerima pendidikan yang dapat membentuk kepribadiannya untuk masa-masa yang akan datang. Pada lingkungan keluarga, orang tua bersama anggotanya mempersiapkan segala sesuatu yang dibutuhkan oleh setiap anggota keluarganya, melalui bimbingan, ajakan, pemberian contoh. Keluarga mempunyai peran mensosialisasikan adat istiadat, kebiasaan, peraturan, nilai-nilai atau tata cara kehidupan.

Menurut Imam Ghozali, anak adalah amanat Alloh kepada kedua orang tuanya. Karena merupakan amanat, maka orang tua berkewajiban untuk melaksanakan pendidikan untuk anak-anaknya sesuai dengan kodratnya. Kesadaran dan keikhlasan merupakan faktor utama bagi orang tua dalam mengasuh, membimbing dan membina anak, sehingga anak dapat berkembang jasmani dan rohaninya sesuai dengan yang diharapkan.

Karena lembaga pendidikan keluarga bersifat kodrati, maka hubungan antara orang tua dan anak harus dilaksanakan atas dasar cinta kasih. Pendidikan dalam keluarga bagi anak mengandung makna sebagai upaya membantu anak untuk dapat hidup sebagai manusia, yang mampu mengembangkan dirinya. Dalam menerapkan pola asuh dalam keluarga, sebaiknya tidak menerapkan pola asuh yang menekankan pada prinsip kalah menang, akan tetapi sebaiknya digunakan pola asuh yang mampu mengembangakn kreativitas pada 
anak sesuai dengan potensi yang dimilikinya.Pola asuh yang tepat digunakan dalam keluarga sebaiknya memiliki karakteristik sebagai berikut: 1) lebih banyak kemungkinan untuk menemukan pemecahan yang bermutu, 2) mengembangkan keterampilan berfikir anak, 3) rasa cinta bertambah, 4) tidak ada pemaksaan, 5) menghilangkan kekuasaan, 6) mengena pada masalah sebenarnya, 7) memperlakukan anak sebagai orang dewasa, 8) sebagai terapi bagi anak.

\section{HASIL DAN PEMBAHASAN}

Mengacu kepada pendapat Amiruddin (2011) ada beberapa hal yang bisa dilakukan orang tua dalam menanamkankepada anak agar dapat menjadi pribadi yang dapat meraih sukses di dunia dan akhirat yaitu:

1) Mantapkan akidahnya

Akidah adalah keimanan yang teguh dan bersifat pasti kepada Alloh dengan segala pelaksanaan kewajiban, bertauhid, dan taat kepada-Nya, beriman kepada malaikatmalaikat-Nya, rasul-rasul-Nya, kitab-kitab-Nya, hari akhir, sahih tentang prinsip-prinsip agama, perkara-perkara yang gaib.

Apabila anak sudah ditanamkan akidah yang kuat dalam keluarga, maka ketika anak ke luar rumah dan ada pengaruh lingkungan yang menerpa dirinya, anak sudah dapat membedakan mana yang baik dan mana yang tidak baik, sehingga akidah dapat dijadikan kerangka dasar dan landasan dalam membentuk anak yang shaleh

2) Baguskan akhlaknya

Akhlak mengandung makna perangai, budi, tabiat, dan adab. Akhlak diartikan sebagai suatu perbuatan yang dilakukan secara berulang-ulang dan bukan perbuatan sewaktu-waktu atau sekali-kali saja. Pembinaan akhlak harus dilakukan sejak kecil terutama melalui keluarga, karena keluarga merupakan lembaga yang pertama dan utama dalam pembentukan akhlak manusia. Orang tua harus mampu memberikan teladan dalam kehidupannya, karena anak akan mencontoh apa yang dilakukan oleh orang tuanya. Perilaku yang tertanam sejak kecil akan menjadi dasar dan terbawa sampai usia dewasa.

3) Rajinkan ibadahnya

Ibadah yang paling utama bagi umat islam adalah sholat, sehingga sholat harus diperkenalkan sejak usia dini, karena sholat merupakan tiang agama. Ketika seorang anak sudah mempunyai kebiasaan untuk melaksanakansholat sesuai aturan, maka insyaalloh tingkah laku anak akan berdampak pada berbagai kebiasaan yang baik, karena dalam dirinya sudah tertanam dan mampu memilih perbuatan yang harus dilaksanakan dan perbuatan yang tidak boleh dilaksanakan.

Selanjutnya menurut Arifah (2011) ada delapan poin upaya yang harus dilakukan oleh orang tua 
cerdas penuh kasih sayang terhadap anak-anaknya yaitu:

1) Berilah anak-anak kita lingkungan untuk tumbuh kembang yang bahagia.

Bahagia bagi seorang anak dapat diciptakan melalui berbagai hal, sehingga bisa menghasilkan stimulasi positif otak anak untuk meningkatkan kecerdasannya. Contoh-contoh yang bisa diciptakan untuk menumbuhkan bahagia anak diantaranya, jauhkanlah pertengkaran diantara orang tua, berkomunikasi dengan anak sesuai kebutuhan, sediakan fasilitas sesuai kebutuhan anak, hargailah semua hasil kerja anak.

2) Latih mandiri, beri kesempatan anak seluas dan sedini mungkin untuk bermimpi, berbuat dan menembus batasan diri mereka. Anak sudah harus dibiasakan sejak usia dini untuk mampu bertanggung jawab pada dirinya sesuai dengan pertumbuhan dan perkembangannya. Ketika masa pertumbuhan berilah kepercayaan kepada anak untuk bergerak, meraih, tengkurap, berjalan dan berlari. Sementara untuk perkembangannya berilah anak kepercayaan untuk makan dan minum sendiri, berkomunikasi, bermain, bersekolah.

3) Tanamkan rasa percaya diri sesudah anak berhasil mandiri sesuai usianya.

Orang tua harus selalu berusaha memotivasi anak dalam mengerjakan sesuatu hal, dan selalu menghargainya, sehingga anak akan merasa tertanam kepercayaan dirinya dalam melakukan sesuatu. Orang tua harus mampu menghilangkan kecemasan dan kekhawatiran yang dirasakan anak dalam mengerjakan sesuatu, tetapi anak diberi kekuatan bahwa mereka mampu untuk melakukan sesuatu hal

4) Bacakan buku yang bagus dan bermanfaat

Orang tua harus menjadi contoh dalam menumbuhkan kebiasaan membaca, sehingga menjadi contoh bagi anak-anaknya. Ketika orang tua sudah biasa membacakan buku yang bagus dan bermanfaat bagi anak, maka anak diharapkan mempunyai hobi membaca yang akhirnya bisa memperoleh informasi sehingga memperluas wawasan pengetahuan, berfikir, sikap, keterampilan yang dapat diaplikasikan dalam kehidupannya.

5) Ajak anak bermain dengan sepenuh hati.

Orang tua mengusahakan bisa bermain dengan anak-anaknya secara bersama dengan memiliki makna yang berkualitas. Orang tua ketika bermain tidak merupakan sisa waktu, tetapi betul-betul menjadi kebutuhan untuk membantu pertumbuhan dan perkembangan anak

6) Ajak anak berkomunikasi, berdiskusi, berfikir, memilih, dan mengambil keputusan sendiri sejak dini. Ketika anak sudah dibiasakan berkomunikasi dengan baik sejak kecil, maka akan menjadi bekal untuk memupuk keberanian dengan penuh tanggung jawab apabila 
dihadapkan pada suatu permasalahan yang harus segera diputuskan

7) Ajak anak bergerak dan berolahraga

Aktivitas anak sejak kecil harus dibiasakan sebagai upaya menjaga kesehatan fisiknya sehingga pertumbuhan badannya bisa secara maksimal sesuai dengan usianya. Anak yang sehat dapat membantu kecerdasan dan perkembangan jiwanya secara maksimal

8) Jauhkan acara televisi yang tidak mendidik

Orang tua harus mampu membimbing dan memilih acara televisi yang tepat untuk ditonton anak-anaknya, sehingga anak tidak terpengaruh jiwanya akibat acara televisi yang tidak sesuai dengan perkembangan jiwanya.

\section{E. SIMPULAN DAN REKOMENDASI}

Berdasarkan UUSPN NO 20 Tahun 2003 pasal 13 jalur pendidikan terdiri dari pendidikan formal, nonformal dan informal. Penyelenggaraan ketiga lingkungan pendidikan tersebut harus didasarkan pada konsistensi, kontinuitas dan konvergensi. Kebijakan tentang pendidikan informal yang tertuang dalam UUSPN No 20 tahun 2003 pasal 27 yaitu:

1) Kegiatan pendidikan informal yang dilakukan oleh keluarga dan lingkungan berbentuk kegiatan belajar secara mandiri

2) Hasil pendidikan sebagaimana dimaksud pada ayat 1) diakui sama dengan pendidikan formal dan nonformal setelah peserta didik lulus ujian sesuai dengan standar nasional pendidikan

3) Ketentuan mengenai pengakuan hasil pendidikan informal sebagaimana dimaksud pada ayat 2) diatur lebih lanjut dengan peraturan pemerintah.

Tugas orang tua dalam menyiapkan pribadi anak untuk meraih sukses dunia akhirat yaitu: 1) mantapkan akidahnya, 2) baguskan akhlaknya, 3) rajinkan ibadahnya.

Upaya yang harus dilakukan keluarga dalam memfasilitasi pertumbuhan dan perkembangan anak dalam keluarga yaitu: 1) memfasilitasi anak untuk tumbuh kembang dan bahagia, 2) melatih kemandirian, 3) menanamkan rasa percaya diri, 4) membantu memfasilitasi buku bacaan yang bermanfaat, 5) mengajak anak bermain sepenuh hati, 6) memfasilitasi berkomunikasi, berfikir, mengambil keputusan setiap dibutuhkan, 7) mengajak bergerak atau beraktivitas, 8) membimbing ketika nonton televisi.

\section{F. REFERENSI}

Amiruddin, A. (2011). Golden Parenting. Sudahkan kudidik Anakku dengan Benar. Bandung: Khazanah Intelektual.

Arifah. (2011). Smart Parenting with Love. Jakarta: Progressio Publishing.

Direktorat PAUD. (2010). Pedoman Teknis Program Penguatan PAUD Berbasis Keluarga (Parenting). Jakarta.

John, G. (2001). Children Are From Heaven. Jakarta: PT. Gramedia Pustaka Utama. 
Megawangi, R. (2003). Pendidikan

Karakter untuk Membangun Masyarakat Madani. IPPK Indonesia Heritage Foundation.

Riana, dkk. (2012).Pendidikan Keorangtuaan dan Keluargadi Indonesia. Bandung: Pusat Pengembangan Anak Usia Dini Nonformal dan Informal Regional 1 Bandung.

Soelaeman, M.I. (1994). Pendidikan

Dalam Keluarga. Bandung: CV. Alfabeta.

Sudjana, D. (2007). Pendidikan Luar Sekolah, Wawasan, Sejarah, Perkembangan,

Falsafah\&Teori Pendukung, serta Azas. Bandung: Falah Production.

Sujiono, Y.N. (2009). Konsep Dasar Pendidikan Anak Usia Dini. Jakarta: PT. Macanan Jaya Cemerlang.

Supriatna, D. (2012). Pendidikan Informal di Indonesia. Bandung: Pusat Pengembangan Anak Usia Dini Nonformal dan Informal Regional 1 Bandung.

Undang-Undang RI No 20 Tahun2003 tentang Sistem Pendidikan Nasional. Bandung: Fokusmedia.

Zubaidi. (2011). Model Pembelajaran Karakter Anak Usia Dini Kelompok Belajar Keluarga (KOLEGA). Bandung: PPPNFI Regional 1 Bandung. 